\title{
RE-EXAMINING ADORNO ON THE REGRESSION OF CONSCIOUSNESS AND DEMOCRACY: TOWARDS SOCIAL TRANSFORMATION
}

\author{
ANSON AU \\ University of Toronto
}

\begin{abstract}
Scholars have charged Adorno of hypocritically abandoning efforts to articulate possibilities of social transformation, a propensity he emphasizes is central to social critique and sociocritical sociology. Keeping consistent with his fundamentally negative position, this essay reexamines democracy by scoping his work and reorganizing its philosophical and sociological contexts to open dialogue on the characteristics of democracy that Adorno would not reject. Throughout, I negatively reflect upon the nature of this democracy and criticize it towards the goal of fleshing out the paths of social transformation possible and available for its realization - through the things it could not be. Adopting this coupling as a point of departure, I analyze the regression of consciousness in Adorno's thought, as the root of egoweakness - the destroyer of maturity and that which underpins every shackle he sees as subjugating the masses - and bring this into dialogue with the insights informed by Hannah Arendt, Leo Strauss, and action theory. To examine the practical implications of social transformation, this essay will also demonstrate how they play out in contemporary contexts, drawing parallels with evidence from contemporary social movements, on account of their conception as a means of social
\end{abstract}

\footnotetext{
Anson Au (anson.au@mail.utoronto.ca) is a Visiting Scholar in the Department of Chinese Literature at the National Sun Yat-Sen University and a PhD student in Sociology at the University of Toronto. Anson's research concerns social networks, organizations \& professions, and East Asia.
} 
transformation and of Adorno's own engagement with this conception.

\section{Introduction}

Kracauer once said to Adorno "you curse [bourgeois society], reject Communism, from down on... Social Democracy... what do you suggest be done?” (Adorno and Kracauer 2008:517), to which the latter replied: "I know and say, what is bad; is this not enough?" (ibid). The charge that Kracauer's critique represents is a serious one: that Adorno hypocritically abandons efforts to articulate possibilities of social transformation, a propensity he emphasizes is central to social critique and sociocritical sociology (Adorno, Horkheimer et al [1953] 1989:151), for the purpose of "[countering] capitulation on the part of those who alone can bring about change" (Benzer 2011:125). One leaves Adorno's work with a view of him not inconsistent with Kracauer's position; Adorno's punishing indictments of the astral body and the foolery circulating in its veins (Adorno 1994:177), ensconced in an overarching assault on exchange society, seemingly makes us bear prescient awareness of how the most probable futures converge on a petrified landscape not different than the one we occupy.

Scholars since Adorno have failed to properly account for his fundamental negative position in issues of methodology (Jung 2013; Keller and Poferl 2016; O’Neill 2008), and effectively prescribed for Adornoian thought a form of identity thinking he himself spited, ignoring the non-identity thinking or "consciousness of nonidentity" (Adorno 2001:17). They have, for instance, imagined him as a champion for a staunchly qualitative program of research and indiscriminately opposed to quantitative approaches (Jung 2013) - a result of emphasizing his observations on how seemingly "individual" cases or data had "general value" in a "refined, discriminating" approach that produced an "abundance of specific, concrete insights” (Adorno 2000:74), whilst, by abandoning his negative position, ignoring how it was the standards of form within quantitative research that he spited, not the methods themselves ( $\mathrm{Au}$ N.d., 2018).

Adorno stood firm in his negative position of rejecting possibilities, more than accepting them, for the reason that the latter would necessarily foreclose potential avenues and ways of thought 
- a mind satisfied with an answer, no longer thinking - otherwise available to the former - a mind perpetually dissatisfied, so perpetually searching and thinking. Thus, the misstep in reading Adorno often arises when we desert this negative position and misinterpret Adorno's critiques for his vision for the future; interpreting, superficially, that his choice to write about what is bad is all that his thought (and the possible futures of a reproduced society dependent on us) consists of, bereft of any idea of good, wherein his books lament our present conditions while nevertheless leaving us bolted in place.

The evidence presented in this article argues that this is not the case: that Adorno does have a specific vision of what social transformation looks like for society, and that the roadmap to attaining it can even come from relying on that which he rejects, albeit for a temporary period of time: heteronomy.

Cook's reading of Adorno offers an insightful glimpse of Adorno's vision of social transformation, whereby certain “'emphatic' concepts, e.g. 'freedom' or 'justice'... faithfully convey what a better society would look like, i.e. unfulfilled normative standards of what society should be” (Benzer 2011:135; Cook 2001, 2005). Moreover, in a deliberation with Becker on the ideals of German education and the workforce, Adorno proffers an elusive endorsement of representative democracy when he engages with Kant:

'Enlightenment is humanity's emergence from selfincurred tutelage.' I believe this forthright program of Kant's is extraordinarily relevant today. Democracy, embodied in the institution of representative elections, depends on the moral development of each individual (Adorno and Becker 1983).

Implicated is the necessity to unearth the normative standards of society's ideal form within his appreciation of democracy - a theme crucial to Adorno's work, but buried in references, rather than explicit treatments, and which produce rejections of its possibilities, rarely yielding any endorsements. 
I do not attempt, on this score, to delineate a positive object (democracy) as the obverse of negative criticism from his thought, but simply aim to flesh out his views on the subject, particularly in the context of his favor for social transformation (Benzer 2011:149) and a world at risk that grows more and more in need of it (Beck 2010). Keeping consistent with his fundamentally negative position, this essay reexamines democracy by scoping his work and reorganizing its philosophical and sociological contexts to open dialogue on a vision of democracy and its characteristics that Adorno would not reject. Throughout, I negatively reflect upon the nature of this democracy and criticize it towards the goal of fleshing out the paths of social transformation possible and available for its realization - through the things it could not be.

Adopting this coupling as a point of departure, I analyze the regression of consciousness in Adorno's thought that sheds new light on these ideals, and engage it with insights informed by Hannah Arendt, Leo Strauss, and action theory. In particular, I focus on the regression of consciousness, amongst the many things Adorno criticizes, as the root of ego-weakness - the destroyer of maturity and that which underpins every shackle Adorno (1994) sees as subjugating the masses, from mass culture production (10), to astrology (59), to common discourses organizing social life (89). To examine the practical implications of social transformation, this essay will also demonstrate how they play out in contemporary contexts, drawing parallels with evidence from contemporary social movements. Social movements serve as an ideal empirical backdrop with which to begin these assessments, on account of their conception as a means of social transformation (Benzer 2011:149150) and of Adorno's own engagement with this conception.

\section{The Regression of Consciousness}

\section{Permanence}

Democracy, for Adorno, was interrupted largely by what he deemed a regression in the human ability to think. For him, the prevalence of occultism or astrology at the time was the surge of nothing more than "a metaphysic of dunces” (Adorno 1994:175), but which was the greatest "symptom of the regression in consciousness", in which "[it] has lost the power to think the unconditional and to endure the conditional” (ibid:172). That is, 
when we submit to the will of the gods, rather than see society - and its problems - as a network of mediated interactions that we constitute, we sit on our hands and abandon attempts to change our reality. This is not the submission of structure to the overwhelming role of agency, but the recognition of our role in replicating structure: as Adorno once countered to Sartre's political existentialism that insisted on the perpetual capacity to choose one's own actions (Sartre 1973:43), "social relations and conditions... [are] a timely addition... [but] structurally hardly more than occasions for action” (Adorno 2001:59-60).

The reference to a regression of consciousness gains further clarity when understood in the context of his comments on the ego and (Kantian) maturity, the latter of which he heavily invests his ideal for individual autonomy:

...maturity requires a certain degree of ego
firmness, as it emerges in the case of the bourgeois
individual. The possibility... that instead of
developing a firm ego, one allows it to adjust to
ever-changing situations, harmonizes in a very
problematic way with the psychological
phenomenon of ego weaknesses (Adorno and
Becker 1983).

An alternate reading of "the regression of consciousness", then, draws parallels with an ego weakness or, put bluntly, intellectual ineptitude. He essentially reaffirms in the same breath that dual propensities for adaptation and individuality fail to counteract ego weakness for the fact that all their pseudo-intellectual efforts and struggles are only prompted by and predicated on the "configuration of rigid obedience and lack of true introjection of norms" (Adorno 1994:107). But Adorno's examination of the socialization process in early childhood in his discussion of psychological autonomy confronts us with an ominous characteristic of the regression of consciousness. Here he references the results of empirical studies in America that demonstrate what might now be called the longitudinal effects of the social conditions of upbringing, where "so-called wellbehaved children tend to become autonomous and critical men and women more so than refractory children, who then as adults 
immediately gather 'round the beer table with their teachers to rally 'round the same slogans" (Adorno and Becker 1983). In other words, the possibilities of changing an ego are foreclosed beyond socialization in childhood. Searching for a remedy in education, he also expresses, "remains too much embedded in the institution of the framework of the school" (109). It is for this reason that recourse to other extant institutions, which cannot escape the logics - profit, exchange - of capitalist society, such as film (109-110), religion (Zeitlin 2001:225-227), etc. which produce efforts that necessarily fail. It follows, therefore, that the regression of consciousness is a permanent state.

\section{Universality}

In addition to the institutionalization of superstition that enables its mass production (Adorno 1994:50), we can identify within Adorno's (1994) indictment of occultism and mass culture, as both symptoms and vehicles of the regression of consciousness, the themes of dependence, estrangement, and integration - themes that run through the rest of his work and which are responsible for proliferating the exchange principle, holding us captive within the petrified conditions of a capitalist present (153-66). They act as instruments of dependence - subjugating man's freedom by exploiting him under the illusion of necessity and through dominion over the relations of production - by selling illusions as a means for distraction from the threat of dreariness (176) and uniting the subject with society's exploitative productivist imperative through a biphasic approach. Deceivingly deemed a work-life balance, the separation of work from play is a cultural lifestyle axiom bound up in contradictory narratives that serve to exploit individuals: work is severed from play, but play is imbued with a sense of duty (pleasure being a "release" from the pressures of labor) - we are thus made to accept the exploitative conditions of work by the solace of play, ensnared in society's productivist apparatus like Huxley's Brave New World (102-3). At the same time, they facilitate estrangement - the objectification of society, wherein its relations and phenomena appear external and alien to us, rather than socially mediated - by attributing everyday occurrences to the movement of the stars and phenomena beyond our control in an unrecognizable, external society and robbing individuals of all agency but the minimum 
needed to conform (ibid.). Combined, they imply social integration or the proliferation of the exchange principle in capitalist society that makes everything commensurable in a world of objects (173), from which we learn that the regression of consciousness is, more or less, universal. By manifesting the "universal principle of [commodity] exchange" (Adorno 2008:95), they further infringe upon the tenets of the human condition by attacking the possibilities of human action, political freedom, and unique personality (Arendt 1968:146) in a way that threatens the communion of man (politics ${ }^{1}$ (Arendt 1973:437-459)) and renders commensurable and subject to exchange, people, who are no longer free. In this way, the regression of consciousness comes to burrow itself in altered political and social conditions that facilitate its encroachment upon more of society.

\section{Unsettling the Regression}

\section{Social Transformation}

In seeking a solution to the problem of unsettling the permanent, universal regression of consciousness buried in the exchange principle and its manifestations, Adorno's pressing calls for social transformation, coupled with his propositions against "piecemeal social engineering” (Popper 1944:122) or small transformations within the capitalist system (Benzer 2011:149), may lead us to the vision of a revolution. ${ }^{2}$ This possibility, and the violence inextricably bound up within its implications, however, would be vehemently rejected by Adorno. In his denunciation of violent praxis (ibid:149-150), Adorno “disobeys the eternal cycle of... violence

\footnotetext{
1 For Arendt, politics was cooperation, not competition; not rigidly defined by the function of repression or individual gain, but bound up in freedom, as a precursor to participation and common action (Cooper 1976; see also Sennett 2012).

2 Popper and Adorno part ways here for their visions of utopia and the role of critical theory. Popper believes that critical thinking is an invariable part of human rationality, and that utopianism, which would destroy this capacity, is something to resist. Popper enlists critical theory as a principal mechanism. Adorno, by contrast, believes that utopia itself is the result of a successful social transformation. Here, Adorno considers critical theory not only as unproductive, effecting changes in the way we think on such a small scale that could never amount to social transformation (piecemeal social engineering), but also as an actual obstacle towards the goal of transformation for its abidance by traditions that reject social transformation (Szrot 2014).
} 
against violence... [he] refuses [his] allegiance to anyone who, after the murder of uncounted millions of humans... still preaches violence" (Adorno 2002:17-18). His antagonism of "violence against violence" as a state of society recalls an analogous critique made by contract theorists of the state of each against all. Juxtaposing the lessons from their struggle with Adorno's position against heteronomy alerts us to:

i. the violence implicated in a state of a society without authority;

ii. the indispensability of authority to resisting this state, and, most importantly:

iii. that Adorno's calls for individual autonomy cannot suffer conflation with a rejection of authority altogether.

It is authority's heteronomous form, where "no one in contemporary society can really lead a life that is self-determined" (Adorno and Becker 1983), and only this form that Adorno takes issue with. For a society that has adopted such a heteronomous form of authority becomes intractable for subjective logical thought (Benzer 2011:189); it realizes Durkheim's society that confronts us as a body of alien objects and phenomena, one where we are subjects, more than agents (Adorno et al 1976:12).

\section{Social Transformation}

Where, then, if not in education, in revolution, or in small activist projects, can we discover the means to uproot the exchange principle, and through it, establish representative democracy? In what forms could critical social theory as "the only viable - and... indispensable - project” (Benzer 2011:147) be actionized? What about protests? The only available efforts remaining inspire recourse to popular movements or to the introduction of enlightened elites. The former, however, dwells dangerously close to a naïve form of activism that adheres to "a pseudo-reality” (Adorno 1998:291) by treating "opponents in discussions as mere instruments for executing their plans, as things" (Benzer 2011:146) or prioritizing the means over the ends. Recent popular mobilizations corroborate an extremized account of this inversion. 
The Global Climate March in November 2015 joins the American Occupy movement (Smucker 2014) and the Hong Kong Umbrella Revolution in demonstrating a tendency toward prefigurative politics, wherein self-expression suffers conflation with content, actions become prefigurations of an actor's vision, and "acts are celebrated for their own sakes" (Gramsci 1991:147). The space itself saw about the representation of a farrago of different, incoherent, issues in signs, costumes, and chants, including: saving the bees, eating vegan, saving the dolphins, starting clean energy, stopping fracking, ending fossil fuel dependence, promoting "systemic change" (left undefined), criticizing Secretary of State for Energy and Climate Change Amber Rudd. When asked about this diversity, a female protester, holding a sign saying "stop bombing Syria” by the Socialist Worker newspaper booth, told me

[The protest] just a place for you to voice your opinion. The climate is just a word. It's about crimes against humanity, it's about solidarity and all coming together to make a message...

Another male protester notes,

[The main message is] essentially fossil fuel and energy change, though there's a lot of stuff going on too... Well bombing Syria was yesterday, and the veganism is really with us, but it's all about people getting together and demonstrating solidarity and making our voices heard...

Me: Do you feel the diversity of the message was a problem?

Him: No, it's all about getting the government to listen to the people (Au 2017a).

The prefigurative tendencies of this protest are not isolated. In a case study of protests stratified across differing themes - foreign affairs, anti-discrimination, peace, policy critiques -, the same tendencies were identifiable. Whether the protest made the immediate structural 
changes it demonstrated against became secondary to the act of protesting itself. At the end of the protest against the British Parliamentary vote for the bombing of Syria in December 2015, I asked whether the protest "had done anything" to different actors scattered across the site, to which they responded:

\begin{abstract}
A Marxism-pamphlet distributor: No, this won't do anything... need an anti-imperial movement, but we need numbers. It's about momentum, and it's important we meet each time to bring more people... People don't join because of pessimism.
\end{abstract}

Officer: The short answer is no it hasn't, but it does matter that they're here... It matters for them.

Young European: Whether it has an effect or not doesn't matter, it is just done to warm people's hearts, whether it's one thousand or one [shrugs] just to warm hearts.

Older female: It's a way to express ourselves and know that I'm not alone." (ibid)

Different actors - even the police, when sympathizing with the protest - consistently referred to the theme of prefiguration. But whilst prefiguration may insulate protesters from the discouragement that failures might create toward present and future mobilization, it ultimately falls upon a Gramscian-utopian narrative that fails to remain sufficiently informed about what it takes for social change to occur - their primary failure, according to Adorno, lies in the maintenance of the status quo, dangerously repackaged as a success in some way. The socialized society thus continues to regulate all living activity, "prescrib[ing] and limit[ing] the conditions of any individual's action” (Adorno 1998:264). Adorno's admonition of naïve activism anticipates the distortion witnessed in the aims of contemporary popular mobilizations, where the means are not simply prioritized over the ends, but the ends have been entirely dissociated from implementing consequential change - the 
tendency to replicate the status quo, though left unchanged, has now brazenly surfaced.

\section{Implications for Action Research}

How do these limits relate to existing accounts of action research? Making sense of action coordination in groups, anticipatory socialization and action theories have contributed by deconstructing the negotiations invested in them. Seminal work by Alfred Schutz (1967) and Pierre Bourdieu (1973, 2000) towards this effort have produced important mediations between phenomenology and Weberian rational action, illuminating the conditions that predict the degree to which actors' protentions - orientations towards the future - and projects - rationally designed plans and aspirations - align to drive action. But where these theoretical approaches have failed to account for non-rationally motivated action, new action theories have underscored the intrapersonal negotiations of future-coordinating within the immediate moment of interaction itself, as pertinent to the interpersonal coordination of action (Tavory and Eliasoph 2013); whereas Schutz and Bourdieu have overemphasized socialized individuals' encounters with an external world, new action theorists have essentially emphasized socialized individuals' encounter with themselves (Au N.d.).

According to Tavory and Eliasoph, modes of futurecoordination "merge, detach, and interlace in everyday interaction... when actors place similar protentions on different narratives, when actors place similar trajectories on different temporal landscapes, or when actors ambivalently orient themselves to multiple futures at once” (2013:909). Thus, the distinction between effectual praxis and ineffectual praxis is captured in the interlacing of such protentions. Ineffectual praxis speaks to a scheme of fragmented naturalized plans - the bedrocks of sedimented values and expectations on which other future-oriented trajectories are performed (Thévenot 2006). Where this normally occurs among actors, the coordination of their protentions can keep an interaction going, albeit with "repair work" to ignore tensions between differing views (Eliasoph 2011). However, ineffectual praxis in protests as an apparent vehicle for social transformation lack this repair work, wherein a diversity of opinions goes without attempt to coordinate or reconcile any of them - that there are none of the usual tensions that normally exist 
between differing views in such a context speaks to how there is no imperative to cooperate in the first place, even within the same temporal landscape.

\section{Orchestrating the Condition for Transformation}

\section{The Agents of Change}

From Adorno's critiques of education, occultism, and activism, the constitution of "the people" he perceives can be distinguished into three constituencies of actors that throw into sharp relief an irreconcilable distrust of these constituencies, underlain by a defeatism that diverts our search for a solution elsewhere. Mediocre mediums and their mediocre audience who accept "the excuse that the world of spirits can convey no more to poor human reason than the latter can take in" (Adorno 1994:95,176) constitute the many, for whom the project of social critique is obviously impossible. Then there are some who are, at best, disillusioned with the status quo, but fail to appreciate the reach of integration, which "encroaches on life intensely enough to render free decision illusory" (Adorno 1996:5960 as cited in Benzer 2011:146); privy to the knowledge that the world needs to be changed, yet they "behave as if one could change the world tomorrow" (Adorno et al. 1976:129). And finally, there are the few who both exhibit maturity or "ego firmness", but whom are often located in the bourgeois individual (Adorno and Becker 1983), and are capable of visualizing the expanse of integration to the effect of actionizing a socio-critical awareness that escapes situation-bound acting (Adorno 1998:264-6, 291), but would remain too few in number to organize anything beyond piecemeal activity.

\section{The Politics of Change and the Human Condition}

The dislocation of the potential for social transformation from (all constituencies of) "the people" prompts two interrelated lines of inquiry in our continued search for an escape from an exchange society and its manifestations: the validity of an electoral democracy, and the potentialities and implications bound up in the use of elites or heteronomous authority as a means. If the people cannot be trusted, then what good is an electoral democracy? Now presented with the case of a dependent, fragmented, and powerless people subservient to even tarot-wielding agents of the exchange principle, the transformation that Adorno urges in contemporary 
capitalist society is compatible with the creation and utilization of elites. That is, rule should be assumed by political figures consisted of the few ego firm and autonomous thinkers capable of sociocritical awareness; their empowerment would involve support from the remaining constituencies of the people, who comprise the majority of society, thus capitalizing on their identification of the ailments of capitalist society and their desire to resist against ideology following its demystification (Adorno 1998:69), but without taxing their ineptitude for social critique.

This builds on the proposition that different social conditions require different types of rule in any given society (Zeitlin 1997:6870). The case of Rome illustrates this principle and the lessons to be gained from it, grounded on striking convergences with contemporary capitalist society: members of society had lost their strong populace integrity by the very conditions that deprived them of authority slackened their sense of autonomy and drove them to depend on authority (ibid); where the deprivation of leadership by oppression under nobles and tyrants had kept the (majority plebeian) Romans servile to Caesar, and thus incapable of restoring their republic, a similar deprivation of autonomy itself has rendered a large proportion of contemporary capitalist society incapable of forming a true electoral democracy, still dependent on authority. Sensitizing ourselves to the congruence between forms of rule and social conditions, we gain insight into the possibility of using an alternate form of rule, more appropriate to current conditions of society, as a means by which (the conditions for) electoral democracy can be obtained.

Indeed, though Caesar became a tyrant, he nevertheless emancipated the people from the existing system of domination, and his popular ascension the very proof of a seized opportunity to inject public interests into the political consciousness of the ruling system. Similarly, the assumption of power by socio-critical thinkers must be succeeded by commitments to remodel the relations of production in ways that expunge heteronomous authority and the exchange principle, and which enable and encourage autonomy, across all of its systems (film, etc.). The achievement of a free-thinking public must precede the relinquishment of power among the former autonomous leaders - to dismantle, by then, the last vestige of heteronomous authority - whose successors would then be 
representatives elected from among the public. Indeed, if dependence to authority is currently irremediable and occupies a locus within modern capitalist society of universal scope, then the greatest hope for its demise is found in itself, made into a means to engineer this reality; its prominence in the future can only be overturned by a temporary adherence to authority in the present - to rely upon heteronomous authority, after which the conditions of autonomy can be established in the political system and egofirmness ${ }^{3}$ disseminated widely across society.

Relying on elites a lá Caesar to lead us towards realizing this vision of a free-thinking, autonomous public, as Adorno also recognized, has its dangers. Attempts by heteronomous orders to control an environment would suffer from the same drawbacks as identity-thinking - they themselves would have to be overturned by the object of their authority. But what an ego-firm authority proposition sets up, consistent with this observation, is a trajectory towards such an overturning succeeded by conditions of a freethinking public. Reliance on ego-firm elites is only temporary until they obtain power and encourage autonomy across all systems, after which they are meant to be over-turned. On another note, one does not explicitly, positively lead from Adorno's thought to an approach of "enlightened elites" as a lesser evil. However, his thought does not preclude such a proposition. In fact, if one were to look for any implicit political stance in Adorno, the most likely one would be the insistence on constant reflection in order to bring together concepts and experience.

In a similar vein, what are the characteristics of this authority, beyond ego-awareness? How do we articulate the conditions for its emergence? This proposition does not forward the same type of elites as Leo Strauss. Strauss cultivates elites as "genuine elites... a selected group of wise men who are devoted to the collective good, and who are freed from ambition and self-interest because of their pursuit of truth" (Halbertal 2007:163). That is, Strauss endorsed a class of political elites who were radical, secretive and duplicitous, and exempt from moral principles it deems applicable to the rest of

\footnotetext{
${ }^{3}$ What I mean by ego-firmness here is maturity in a Kantian sense, where an individual is capable of mustering the will to autonomously think, against the foil of what Adorno refers to as ego-weakness or immaturity, the inability to think against conventional cultural norms in any setting (Adorno and Becker 1983).
} 
humanity (Drury 1988:xix; see also Strauss 1968), and whose "natural right" as "the stronger [was] to prevail" (see Strauss 1952). This form of elitism is, as critics have noted, doomed to fail, for "humans, even those who devote themselves to truth, are always embedded within the boundaries of the human condition," (Halbertal 2007:163) in particular elites who are relieved by Strauss of political responsibility, reflection, and moral principles.

The question of authority and elites instead draws lineages between Theodor Adorno and Hannah Arendt to shed new light on the characteristics of such elites who would lead and dismantle heteronomy. In a scenario with fewer ego-firm than the many egoweak, power, defined in Arendtian terms as an emergent property of "togetherness" or collective action and speech (1958:178), would be unequally distributed and clustered around the ego-firm - in other words, togetherness or collective activity would be organized around the leadership of these individuals. For Arendt, the fate of the term "elite" draws from a radically different place than Strauss, who are not social, cultural, or professional elites, self-chosen "from those who care about public freedom and happiness... in stark contrast to so-called elite theories of democracy" (Hansen 1993:190). Arendt's elites are not self-selected among political elites, but self-excluded, to the effect of reinforcing a freedom from politics and the ability to govern oneself as a genuinely human experience. After all, just as freedom in a public realm "provides for those qualities which can only be expressed among others who share a world in common, freedom from politics allows for the flourishing of intimacy, and the qualities of love and compassion" (ibid) - the anticipation of elites who are not only capable of wielding power, but capable of continual reflection, summoned by a genuine concern for people that is lost to a Straussian view of power as an irreconcilable right of the strong. As such, authority - anchored in power as the capacity to be obeyed unreflectively - is easily manifested and wielded - by those who wield influence reflectively - to enact the conditions that presuppose a new consciousness of maturity, bringing a novel mode of participation to irrupt into the status quo from within itself.

Bernie Sanders illustrates a recent example of this form of egofirm elite and demonstrates the potential of creating such an elite to lead the masses. Disillusioned with the exploitative tendencies of modern governance, he headed a campaign entirely supported by 
popular support in an effort to effect structural change. Despite his failure, he successfully mounted a powerful challenge against those who would keep the status quo, whilst pulling many people from political apathy and disengagement to active participation in politics, such as youth voters (Kawashima-Ginsberg et al 2016). Thus, the scale on which this would operate is not the evisceration of capitalism in its petrified conditions; it should only aim to inform and improve political participation and awaken political freedom from the illusion that it currently inhabits.

After all, I do not, by this proposition, suggest there is an outside to heteronomy in the current social structure we should begin searching for - on the contrary, I recognize, and it is because there is no outside that we must begin looking within it. This proposition also does not intend to invoke Leninist sentiments concerned with the dismantling of the state. Such arguments are aplenty in contemporary populist movements launching broad indictments against a nebulous "establishment", but whose protests are sadly fated to the "impatient praxis" seeking to change an uninterpreted world and, as a result, to the disappointed conduct of prefigurative politics that never move beyond utopianism and action for action's sake - to weakness and failure (Adorno 1998:265).

\section{A New Mode of Resistance}

The ways in which political resistance and dissension are enacted, it follows, desperately need a transformation in form and vision. In the wake of mass political unrest around the globe over issues of exploitation and inequality, the need for effectual praxis becomes paramount. But critique alone is insufficient without suggestions for solutions - so what makes for effectual praxis?

Marx's eleventh thesis has become one of the most widely cited rallying cries for contemporary protests: "the philosophers have hitherto only interpreted the world, but the point is to change it" (Marx 1888). Yet the failures of major social movements and the wasted populism of countless supporters urge caution about its implications for action: action must not rule out interpretation. The perilous consequences of action alone have been made clear across time in impatient and ineffectual praxis, such as the 1968 French revolts and 'their 'barricades' against 'those who administer the bomb' [which] illustrate contemporary activism’s misled, 
inconsequential, even 'ridiculous' operations” (Adorno 1998:269 cited by Benzer 2011:146) - and the incarnation of similar practices in modern activism, such as the assorted costumes and disconnected signs that pervaded the 2015 Global Climate March. Indeed, effective praxis or action must be preceded by interpretation, and succeeded by practical objectives.

Prefiguration and its aforementioned qualities are the failed form of political collective action, at once the result of lack of interpretation, and the taking the place of practicality as a strategic outlook for protesters (Au 2017b,c). That is, maybe "we tried to change the world too quickly. The time is to interpret it again, to start thinking” (Zizek 2012). Only by interpreting the conditions surrounding a political process or phenomenon can strategies be designed and enacted to the greatest effect. In a similar vein, interpretation lends insight to the development of practical goals indispensable to effective political action.

It is the widely held belief among protests that the further resistance objectives are pushed into deeper abstractions, the more support they are likely to attract (Au 2016; 2017a,d). The 2015 Global Climate March attracted tens of thousands of protesters across both London and Paris under the broad, collective challenge of "saving the earth." The virtually limitless boundaries of its criteria for membership were essential for attracting the support that it did, but also in the forms that it did - unbound and unrelated opinions. Whilst these tendencies are often justified by the social function of "raising awareness," their efforts nevertheless failed to move beyond defeat and prefiguration. Nothing emerged as a direct result of the March. Thus, though attracting support through abstract goals is an alluring tactic, its prediction of effective action is tenuous at best.

Further comparisons beyond Western societies corroborate the same admonitions about a broader, unfocused support-base versus a more restricted, focused one. In the fall of 2014, for instance, had Occupy Central activists in Hong Kong refined their political goals around hard, immediate policy changes, in lieu of the general calls for universal suffrage that they advanced, they may have succeeded in setting the grounds for more representative elections, as with their Taiwanese counterparts in Occupy Parliament just a few months prior in the spring of 2014, who insisted on the termination of a trade agreement - and succeeded. Despite the convergences in the two 
movements around their resistance against an encroaching Chinese influence in local governance and their shared vision of independence from China, the Hong Kong protesters conflated this vision with their goals (Lam 2015), whilst the Taiwanese protesters distinguished the two and instead focused on resisting a specific policy proposal (Ho 2015). The distinction between the two forms of support lies in the degree to which they generate a cohesive sense of collective identity among their members, necessary for continued concerted action that ultimately motivates policy changes past the termination of individual protests. This is not inconsistent with Adorno's indictments of ineffectual praxis (concerted political action). One should not behave, Adorno warns, as if one was capable of changing the world (Adorno et al 1976:129) or structure one's efforts around pseudo-reality (Adorno 1998:291), for it, in turn, produces pseudo-activity that only feigns control over reality failing to interpret it - and serves to replicate the status quo.

On this score, I do not identify as pseudo-activity or ineffectual praxis all protest activity, but only that which has abandoned practical, achievable goals that do not venture into the abstract (i.e. dismantling capitalism) nor the disconcerted (i.e. a plethora of different goals). Nuanced, specific, and attainable goals that trade abstractions for practicality best prevent strategic vision from breaching pseudo-reality by remaining better focused on reality as is presently lived. Praxis, it stands, answers Adorno's calls for social transformation when preceded by interpretation, extending the continuous project of critical social analysis (Adorno 1996:243) and connecting it with action, and succeeded by practical objectives, circumventing pseudo-reality and prefiguration.

\section{Discussion: The Negative Position Revisited}

Did Adorno endorse democracy? The answer, though an elusive yes, warrants a perusal through his work to identify the standards that he envisioned for democracy, piecing together the ideal standards from references scattered throughout his writings and interviews. Yet, efforts to do so must remain consistent with his fundamentally negative position, detecting what his vision of democracy was only through what it could not be. The result is the temporary empowerment and reliance on a variation of heteronomous authority itself: elites who could overturn the 
regression of consciousness buried in the exchange principle and its manifestations.

This proposition anticipates criticism on several accounts, which I will attempt to address here. First, it invites a charge of elitism. Adorno, however, was not elitist in the same terms that his critics describe. In his conversation with Becker, he repeatedly rejects talent and its iterative categories. Asserting that the "fetishization of talent... should be abolished", he was committed to disproving the veracity of its base assumption as the romantic product of genetics, when in fact, it is "in large part a function of social conditions" (Adorno and Becker 1983). And where he admits the ego strength of the bourgeois individual (ibid), the theoretical preoccupation of his socio-critical project remains critical of society from a position on ego strength that extends beyond the limitations of individuals (Benzer 2011:126), much like how Marx’s "hatred... [was] much more against ideologues than... against the members of the ruling class” (Adorno 2008:116). Moreover, his critique of high art, which "deny the commodity society by the very fact that they obey their own law" (Adorno and Horkheimer [1944] 1997:157) lays bare his rejection of anything treated as independent of the relations of production. $^{4}$

Second is the obvious confrontation it prescribes with Adorno's hatred for heteronomous authority itself. But would Adorno's hatred for heteronomous authority outweigh his distrust of the masses in a way that allows for an alternative solution? Since, as detailed throughout this paper, Adorno would answer in the negative, to reject a proposition involving the use of heteronomous authority,

\footnotetext{
4 This is because, Adorno's critique of Benjamin's thesis about film illustrates, nothing can truly claim to be independent of relations of production. Benjamin acknowledges film as an art form for "focusing on hidden details of familiar objects" and "exploring common place milieus under the ingenious guidance of the camera" to "extend our comprehension of the necessities which rule our lives and assure us of an immense and unexpected field of action" (1968:236-7). Adorno, by contrast, regarded this endorsement of film as uncritical, remarking to Benjamin that both high art and industrially produced consumer art "bear the stigmata of capitalism, both contain the elements of change... Both are torn halves of an integral freedom, to which, however, they do not add up" (Adorno quoted in Bernstein 2001:2, also Demiryol 2012). More centrally, the redemptive power of film does not overcome the restrictions inflicted by its dependence on an institution of cultural production defined by the logics of profit and exchange in capitalist society (Adorno and Becker 1983).
} 
despite the potential it holds for its very dissolution, serves to prioritize the means above the ends, returning to ineffectual praxis. Commitment to effectual praxis informed by socio-critical awareness would, then, tolerate a temporary adherence to heteronomous authority in prioritizing the ends above the means.

Third, the proposition of relying upon elites is not deductively concluded from Adorno's stance. Fourth, and related, the closest approximation of a reflection among political agents - the elites, in my proposition - may also be an activist slogan associated with the Zapatistas (“Asking, we walk”). I accept the critique that my assessment is just as compatible with elites as with anarchist movements or other anarchist possibilities, but do so at the same time as I stress the acknowledgement that Adorno's thought leaves open all these possibilities.

Adorno's procedure is typically first to criticize A and then nonA - hence the preferred form for his criticism is the chiasmus, as Susan Buck-Morss, among others, has pointed out (see Buck-Morss 1979). In other words, it cannot be concluded from his criticism of A that he implicitly affirms non-A, and so I do not positively deduce the assumption that he is affirming or explicitly endorsing an egofirm elite in the path to social transformation in democracy. Rather, I aim to simply tease it out as a possibility - one that he has not rejected and leaves open, which can be made congruent with the pursuit of social transformation.

Although the roads to social transformation appear narrow in the escapable heteronomy of the present social structure, we can identify within Adorno's standards a new program for effectual praxis in political resistance consisting of action, interpretation, and practicality as inextricable components that do not violate his admonishments against ineffectual praxis - and anticipate the precursors for the prospects of its arrival from within. 


\section{References}

Adorno, Theodor. 1994. The Stars Down to Earth and Other

Essays on the Irrational in Culture. London: Routledge.

Adorno, Theodor. 1996. "Negative Dialektik. Jargon der

Eigentlichkeit.” Vol. 6 in Gesammelte Schriften, edited by Rolf

Tiedemann. Frankfurt am Main: Suhrkamp

Adorno, Theodor. 1998. Critical Models: Interventions and

Catchwords. Translated by H. Pickford. New York: Columbia

University Press.

Adorno, Theodor. 2000. "Introduction to Sociology”, translated by

E. Jephcott. Stanford University Press.

Adorno, Theodor. 2001. Negative Dialectics, trans. D. Redmond.

URL: www.efn.org/ dredmond/ndtrans.html.

Adorno, Theodor. 2002. "Who’s Afraid of the Ivory Tower?",

translated by G. Richter. Monatshefte 94(1):10-23.

Adorno, Theodor. 2008. "Philosophische Elemente einer Theorie

der Gesellschaft.” Vol. 12 in Nachgelassene Schriften, Pt IV:

Vorlesungen, edited by Tobias ten Brink and Marc Phillip

Nogueira. Frankfurt am Main: Suhrkamp.

Adorno, Theodor, Hans Albert, Ralf Dahrendorf, Jurgen

Habermas, Harald Pilot, and Karl R Popper. 1976. The

Positivist Dispute in German Sociology. Translated by Glyn

Adey and David Frisby. London: Heinemann.

Adorno, Theodor and Hellmut Becker. 1983. "Education for

Autonomy.” Telos 56: 103-110.

Adorno, Theodor and Max Horkheimer. [1944] 1997. Dialectic of

Enlightenment. New (English) Edition. London: Verso

Classics.

Adorno, Theodor and Siegfried Kracauer. 2008. Der Riß der Welt

geht auch durch mich...' Briefwechsel 1923 1966. In Theodor

W. Adorno Briefe und Briefwechsel. Vol. 7, edited by

Wolfgang Schopf. Frankfurt am Main: Suhrkamp.

Adorno, Theodor, Max Horkheimer, and Eugen Kogon. [1953]

1989. “Die Menschen und der Terror” in Horkheimer 1989:

143-51.

Arendt, Hannah. 1958. The Human Condition. Chicago, IL:

University of Chicago Press. 
Arendt, Hannah. 1968. Between Past and Future, Revised Edition. New York, NY: Viking Press.

Arendt, Hannah. 1973. The Origins of Totalitarianism, Third Edition. New York, NY: Houghton Mifflin Harcourt.

$\mathrm{Au}$, Anson. 2016. "Reconceptualizing Online Free Spaces: A Case Study of the Sunflower Movement.” Journal of Contemporary Eastern Asia 15(2):145-161

Au, Anson. 2017. "Reconceptualizing Social Movements and Power: Towards a Social Ecological Approach.” The Sociological Quarterly 58(3): 519-545.

Au, Anson. 2017b. “A Social Ecological Approach for Ethnography: Flexibilizing Roles and Remembering Social Embeddedness.” Thinking Methods: Explorations in Social Research Methodology. Published Online:

http://blogs.lse.ac.uk/thinkingmethods/2017/01/02/a-socialecological-approach-for-ethnography-flexibilizing-roles-andremembering-social-embeddedness/

Au, Anson. 2017c. "Anti-Sinoism and the Sunflower Movement: The Future of Ethnic Conflict in Taiwan.” Berkeley Journal of Sociology. Published Online:

http://berkeleyjournal.org/2017/04/the-sunflower-movementand-the-taiwanese-national-identity-building-an-anti-sinoistcivic-nationalism/

Au, Anson. 2017d. “Collective Identity, Organization, and Public Reaction in Protests: A Qualitative Case Study of Hong Kong and Taiwan.” Social Sciences 6(4). Art. 150. DOI: 10.3390/socsci6040150

$\mathrm{Au}$, Anson. 2018. "Sociology and Science: The Making of the Social Scientific Method.” The American Sociologist 49(1): 98-115.

Au, Anson. N.d. "Positioning the Undialectical within the Dialectical: Contributions to Theorizing.” Unpublished Manuscript. Department of Sociology, University of Toronto.

Beck, Ulrich. 2010. "Climate for Change, or How to Create a Green Modernity?” Theory, Culture, and Society 27(2-3):254266. 
Benjamin, Walter. 1968. Illuminations. Edited by H. Arendt, translated by H. Zorn. New York: Schocken Books.

Benzer, Matthias. 2011. The Sociology of Theodor Adorno. New York: Cambridge University Press.

Bernstein, Jay M. 2001. “Introduction” Pp. 1-25(2) in Theodore W. Adorno, Culture Industry: Selected Essays on Mass Culture, edited by J. M. Bernstein. London: Routledge.Bourdieu, Pierre. 1973. “The Algerian Subproletariat.” Pp. 83-92 in Man, State and Society in the Contemporary Maghreb, edited by I.

Zartman. New York: Praeger.

Bourdieu, Pierre. 2000. Pascalian Meditations. Stanford: Stanford University Press.

Buck-Morss, Susan. 1979. The Origin of Negative Dialectics. New York: The Free Press.

Cook, Deborah. 2001. “Adorno, Ideology and Ideology Critique.”

Philosophy \& Social Criticism 27(1): 1-20.

Cook, Deborah. 2005. "From the Actual to the Possible:

Nonidentity Thinking”. Constellations 12(1): 21-35.

Cooper, Leroy A. 1976. Hannah Arendt's Political Philosophy: An Interpretation. The Review of Politics 38(2): 145-176.

Demiryol, Gaye I. 2012. "Film as a mobilizing agent? Adorno and Benjamin on aesthetic experience.” Philosophy and Social Criticism 38(9):939-954.Drury, Shadia. 1988. The Political Ideas of Leo Strauss, New York: St. Martin's Press.

Eliasoph, Nina. 2011. Making Volunteers: Civic Life after

Welfare's End. Princeton, N.J.: Princeton University Press.

Gramsci, Antonio. 1991. Prison Notebooks. Edited by Joseph A. Buttigieg. New York: Columbia University Press.

Halbertal, Moshe. 2007. Concealment and Revelation: Esotericism in Jewish Thought and its Political Implications. trans. Jackie Feldman, Princeton: Princeton University Press.

Hansen, Phillip. 1993. Hannah Arendt: Politics, History and Citizenship. Thousand Oaks: Stanford University Press.

Ho, Ming-Sho. 2015. “Occupy Congress in Taiwan: Political Opportunity, Threat, and the Sunflower Movement.” Journal of East Asian Studies 15(1):69-97. 
Jung, Matthias. 2013. “Das ‘Joch der Methode’. Adornos

Selbstverständnis als Sozialforscher und sein Beitrag zum

Paradigma qualitativer Forschung. Zwei Briefe aus den

Anfangstagen des

'Princeton Radio Research Project.'” [64 Absätze]. Forum

Qualitative Sozialforschung / Forum: Qualitative Social

Research, 14(3), Art. 9,

http://nbn-resolving.de/urn:nbn:de:0114-fqs130394.

Kawashima-Ginsberg, Kei, Noorya Hayat, Abby Kiesa, \& Felicia

Sullivan. 2016. “2016 Election: Donald Trump and Young

Voters.” The Center for Information \& Research on Civic

Learning \& Engagement. Published online:

https://civicyouth.org/wp-content/uploads/2016/06/Trump-and-

Youth-Vote.pdfKeller, Reiner and Angelika Poferl. 2016.

Soziologische Wissenskulturen zwischen individualisierter

Inspiration und prozeduraler Legitimation. Zur Entwicklung

qualitativer und interpretativer Sozialforschung in der

deutschen und französischen Soziologie seit den 1960er Jahren

[76 Absätze]. Forum Qualitative Sozialforschung / Forum:

Qualitative Social Research, 17(1), Art. 14,

http://nbn-resolving.de/urn:nbn:de:0114-fqs1601145.

Lam, Jermain T.M. 2015. "Political Decay in Hong Kong After the Occupy Central Movement.” Asian Affairs: An American

Review 42: 99-121.

O’Neill, Maggie. 2008. “Transnational Refugees: The

Transformative Role of Art?” Forum Qualitative

Sozialforschung / Forum: Qualitative Social Research, 9(2),

Art. 59, http://nbn-resolving.de/urn:nbn:de:0114-fqs0802590.

Popper, Karl R. 1944. “The Poverty of Historicism II: A Criticism

of Historicist Methods.” Economica 11(43): 119-37.

Sartre, Jean-Paul. 1973. Existentialism and Humanism, trans.

P.Mairet. London: Methuen.

Schutz, Alfred. 1967. The Phenomenology of the Social World.

Evanston: Northwestern University Press.

Sennett, Richard. 2012. Together: The Rituals, Pleasures, and

Politics of Cooperation. New Haven: Yale University Press.

Smucker, Jonathan M. 2014. "Can prefigurative politics replace political strategy?” Berkeley Journal of Sociology. Retrieved 
July 30 from: http://berkeleyjournal.org/2014/10/canprefigurative-politics-replace-political-strategy/

Strauss, Leo. 1952. Natural Right and History. Chicago: University of Chicago Press.

Strauss, Leo. 1968. On Tyranny. Ithaca: Cornell University Press.

Szrot, Lukas. 2014. Popper, Adorno, and the Methodology

Dispute. TELOSscope. Retrieved online:

http://www.telospress.com/popper-adorno-and-themethodology-dispute/

Tavory, Iddo and Nina Eliasoph. 2013. "Coordinating Futures:

Toward a Theory of Anticipation.” American Journal of Sociology 118(4):908-942.

Thévenot, Laurent. 2006. L'action au pluriel: Sociologie des régimes d'engagement. Paris: Éditions la Découverte.

Zeitlin, Irving. 2001. Ideology and Development of Sociological Theory, 7th edition. Upper Saddle River, NJ: Prentice Hall.

Zeitlin, Irving. 1997. Rulers and Ruled: An Introduction to

Classical Political Theory from Plato to the Federalists.

Toronto, ON: University of Toronto Press.

Zizek, Slavoj. 2012. “Don’t Act. Just Think.” Big Think. Retrieved February 6, 2017:

https://www.youtube.com/watch?v=IgR6uaVqWsQ\&t=51s 